\title{
The Impact of Knowledge Management and Digital Literacy to create Opportunities in the 4.0 Industrial Revolution Era
}

\author{
M. Ali Ghufron ${ }^{1}$, Harisa Mardiana ${ }^{2}$ \\ \{soehanadiharisa@gmail.com\} \\ ${ }^{1}$ Universitas Indraprasta PGRI \\ ${ }^{2}$ Universitas Buddhi Dharma
}

\begin{abstract}
The use of digital literacy as a knowledge and add the value of innovation are the purpose of this research which is needed in 4.0 Industrial Revolution. By sharing, applying and creating knowledge are the valuable lesson learned to foster continued of learning organization. The fact is many of the educators, lecturers, staff members of universities, technicians and students have difficulty in managing the knowledge of digital literacy and the impact is to lose the opportunities in the era of Industrial Revolution 4.0. There are 142 respondents of the research which are from lecturers, staff member of universities, technicians and students from several university in Tangerang City, Banten, Indonesia. The method of the research is mixed-method of quantitative and qualitative. The result of the research is most of the respondents (111 respondents or $78 \%$ ) moved to manage the new literacies and the other of (31 respondents or $22 \%$ tried to manage themselves to manage the knowledge of digital literacies. This research found that losing digital literacy knowledge would lead to a loss of opportunity in 4.0 Industrial Revolution era.
\end{abstract}

Keyword : Students, Opportunities, Industrial.

\section{Introduction}

As the technology changes people work, the organization especially the universities need to re-evaluated and adjusted for future learning. The changing makes the way of working unrecognizable and it is not only constant work but also exponential its pace and scope as resulting on emphasizing on technological innovation and digital productivity [1]. The staggering confluence of emerging technology breakthrough the way people work, especially in the university. Moreover, Schwab, K in World Economic Forum, 2017 described that the extent and nature of the Fourth Industrial Revolution is in the scale, scope and complexity of humankind has experience and the people need to grasp fully speed to unlimited possibilities of having billion people connected by mobile devices, giving rise to unprecedented processing power, storage capabilities and knowledge access. In the era of 4.0 Industrial Revolution, all companies included the universities increasingly require the validation of digital literacy skills which can be employability. As the major roles in the organization, the aspect of technology is a must improve the efficiency and increase productivity. The problem is in Tangerang City that most university members are ignored about the digital literacy, and they do not want to change the behavior to learn more about the digital literacy. Some of them do not know how 
to use digital literacy, and some of them have difficulty following the use of digital literacy [2]; [3]; [4]. Sometimes they have frustrated when dealing with digital literacy. It seems hopeless and they choose not to do it anymore. Moreover, they need to learn to manage the digital literacy knowledge which is digital capabilities and digital information discernment [5].

In the previous research was written by Wiśniewska-Sałek (2019) interpreted that the knowledge management as managing the digital literacy so as to start the job will be consistent with the requirements and university needs in the future, while with appropriate knowledge and competences is in line with the decision making process. Another research by Belisle (2006) revealed that the digital literacy knowledge contexts in 21st-century skills are being deployed is facing a major challenge. Digital technologies are evolved not only by transforming access but fostering new approaches to knowledge and emerge the issues for education which is described as part of the ongoing digital knowledge revolution. The researcher Hargittai, E, (2009) indicated that the employees need to be able to think in technological term and understand the solution can be achieved through the use of technology. Furthermore, the management capability which drive to enable institutions to steer in the interconnectivity between system, machines and people across the value network. With the digital literacy knowledge competency together with managing the digital knowledge, it will unlock the opportunity to the world which acquires the skill set that gives the same opportunities across the board, across divide by the technology [15]. To help ensure the university members who have difficulty in technological change, the university must support digital literacy modules in workforces development programs such as training, coding boots and mentoring the program that expose to technology and professionals skills. With develop of methodological of serving as the foundation for sustainable development goal, the university members are able to achieve at least a minimum level of proficiency in digital literacy skills management [16]. The author of this research concluded that digital literacy is knowledge to pursue people need in Industrial Revolution 4.0 era and people need to manage the knowledge of digital literacy, so that they will not lose the opportunity. The purpose of the research is to investigate the competency of digital literacy knowledge and to seek the management of knowledge for the members of universities in Tangerang City area, Banten, Indonesia which creates the opportunities in the Industrial Revolution 4.0 era.

\section{Methodology}

This research was conducted to investigate the competence of digital literacy knowledge for university members in the Tangerang City area, Banten, Indonesia so as to create competitive employment opportunities in the Industrial Revolution 4.0 era and also to find the capable solution for each members of universities. The sampling was applied to 142 respondents which consists of universities officials, scholars, lecturers, staffs, employees, technicians, computer lab technicians from several university in Tangerang City, Banten, Indonesia. The research design is mixed-method approaches of quantitative and qualitative [17]. Data collection technique from officials, staff, employees, technician, laboratory technician, lecturers and students with no requiring of the respondents' ages was collected by giving questionnaires on Google Form in September - December 2019, the interviews and data analysis to investigate. Data collection technique, regarding to the qualitative was collected by giving the interview to 14 university members who work close to the author with last 2-3 hours in October-November 2019. Demographic profiles to this research showed that 
the official $12(8.45 \%)$, staffs 20 ((14.08\%), employees 23(16.19\%), technician $11(7.75 \%)$, laboratory technician 5(3.5\%) lecturers $30(21 \%)$, and students $41(28.87 \%)$. To measure reliability, it is shown of the reliability of knowledge management is 0.825 ; and digital literacy competency is 0.771 and the knowledge management and digital literacy members is 0.748 . All of the reliability showed strong and reliable.

The hypothesis of the impact of knowledge management and digital literacy to create opportunities in the 4.0 Industrial Revolution era are:

a) There is a digital literacy competency knowledge in the university members

b) Knowledge management is needed for digital literacy in the university members

c) There is an impact of knowledge management and digital literacy to create opportunities in the 4.0 Industrial Revolution

\section{Result and Discussion}

In interpreting data of knowledge management and digital literacy to create opportunity in the 4.0 Industrial Revolution era, it is used frequency of the data. The reason to measure by frequency is to find the respondents that move to use digital literacy and knowledge management in creating opportunities in 4.0 Industrial Revolution era. To describe the respondents' knowledge of digital literacy and knowledge management, the author showed the characteristic of respondents and this was indicated on questionnaires.

Table 1. Descriptive statistic of knowledge management and digital literacy

\begin{tabular}{|c|c|c|c|c|c|}
\hline \multicolumn{6}{|c|}{ Knowledge Management } \\
\hline Official & 33.12 & 33.0 & 3.0 & 4 & 33.3 \\
\hline Staffs & 33.05 & 33.0 & 2.19 & 5 & 25 \\
\hline Employees & 33.17 & 33.0 & 1.85 & 6 & 26.1 \\
\hline Technicians & 33.83 & 34 & 2.27 & 3 & 27.3 \\
\hline Laboratory Technician & 33.0 & 33.0 & 2.55 & 5 & 100 \\
\hline Lecturers & 35.16 & 34 & 3.05 & 17 & 56.66 \\
\hline Students & 35.65 & 34.39 & 3,51 & 34 & 75.55 \\
\hline \multicolumn{6}{|c|}{ Digital Literacy } \\
\hline Official & 33.10 & 34 & 3.08 & 4 & 33.3 \\
\hline Staff & 33.2 & 34 & 1.74 & 5 & 25 \\
\hline Employees & 33.13 & 33 & 1.76 & 6 & 26.1 \\
\hline Technicians & 33.9 & 34 & 1.51 & 5 & 100 \\
\hline Laboratory Technician & 32.6 & 33 & 1.82 & 5 & 36 \\
\hline Lecturers & 34.2 & 35.9 & 4.2 & 15 & 51 \\
\hline Students & 36.02 & 35.90 & 5.09 & 41 & 93.33 \\
\hline \multicolumn{6}{|c|}{ Creating Opportunities } \\
\hline Official & 76.83 & 70.3 & 3.96 & 7 & 58.33 \\
\hline Staffs & 70.25 & 71.60 & 3.22 & 10 & 64.89 \\
\hline Employees & 69.2 & 70.10 & 4.00 & 17 & 60.86 \\
\hline Technicians & 74.33 & 74 & 3.64 & 9 & 81.81 \\
\hline $\begin{array}{l}\text { Laboratory } \\
\text { Technicians }\end{array}$ & 73.98 & 74.07 & 4.57 & 5 & 100 \\
\hline
\end{tabular}




\begin{tabular}{llllll}
\hline Variables & \multicolumn{2}{c}{$\begin{array}{c}\text { Means } \\
\text { Knowledge Management }\end{array}$} & $\begin{array}{c}\text { Median } \\
\text { SD }\end{array}$ & Freq. & $(\boldsymbol{\%})$ \\
\hline Lecturers & 77.48 & 78 & 4.98 & 23 & 77.77 \\
\hline Students & 78.45 & 79.09 & 4.48 & 40 & 97.56 \\
\hline & & & & 111 & 78.16 \\
\hline
\end{tabular}

The understanding of digital literacy has shifted so far, encouraging workers such as officials, staffs, employees, lecturers and students to be encouraged to have the advanced ability and advanced skilled. Shifting the workforce who understands technology adds to the burden of relearning and can manage the knowledge gained in a digital [18]. From data above, this research showed that with this problem, the universities and with the support of interview from the respondents must train the members to understand knowledge management so all of data must be in documented management systems which campus should make the infrastructures such as to store the company documents on the cloud, share them and control access permission at a granular level [9]; [12]; [20]. The training may take longer time, with teach transfer to the members of university whose members are complex individuals and have different way of difficulty, the training will help the members to comprehend the idea and it will apply to their knowledge to solve a real-work problems [19]; [1]; [21]. As the interview had taken a part, most respondents stated that with all hurdles empowered to act on input from below or the bottom, and the managers compelled to adopt a short-term outlook to work. The development of institution or university requires a level of competence in the field of information technology, the idea of digital literacy that has the ability to complement every individual in the organization which must learn and work in a digital society and must be taken seriously [22]. From 142 respondents, there are 111 respondents clearly understand to create opportunities in 4.0 Industrial Revolution era and 31 respondents do not understand how to create the opportunity in 4.0 Industrial Revolution. Respondents in official have 7 from 12 respondents. It is good enough, it means they care about the future learning. In staff respondents, from 20 respondents, there are 10 respondents who understand and care of creating opportunities. Half of the respondents have improved themselves in knowledge management and digital literacy and as the interview had taken a part, they are sure that they need to understand and use knowledge management and digital literacy to bring the good future opportunity. In employees section, there are 23 respondents and 17 respondents have moved to have knowledge management and digital literacy. And the rest is 6 respondents who are still trying to learn more about knowledge management and digital literacy. For the technician, from 11, there are 9 respondents have improved knowledge management and digital literacy. As the interview had done, they have realized that for the future job, they need to learn more about the new technology, not only they use the hand, but also they use the computer. For laboratory technicians, all of 5 respondents understand clearly about knowledge management and digital literacy. From all respondents, only laboratory technicians consistent with their knowledge and skills. They are ready for future job by having technological change. For lecturers, from 30 lecturers, there are 23 lecturers as respondents have improved their knowledge management and digital literacy. The rest of the lecturers, (7), need to improve to learn about digital knowledge and how to manage it. The lecturers understand that they have to move to technological change for future job otherwise, they will lose the opportunity. The last is students, from 41 students, there are 40 students are ready for technological change. Besides, they understand about the knowledge management, they are able to perform the digital literacy. Only one (1) student has tried to improve to change. When the interview had taken a part, the students prefer to learn or study by using technology such as the Internet, 
computer and social media. They are active to manage their knowledge and improve their digital literacy. The inability of members in universities does not need to be isolated and must be trained continuously, because training and developing working with hands skills will facilitate employment service [23].

Table 2. Descriptive statistics Relationships of Knowledge Management, Digital Literacy and Creating Opportunities in 4.0 Industrial Revolution

\begin{tabular}{lcllll}
\hline \multicolumn{1}{c}{ Variables } & \multirow{2}{*}{ R } & \multirow{2}{*}{ R Square Change } & \multicolumn{2}{c}{ Change Statistic } \\
\cline { 4 - 5 } & & & F Change & Change Statistic \\
\hline KM-Opportunity & 0.735 & 0.540 & 164.146 & 0.000 \\
\hline DL-Opportunity & 0.775 & 0.556 & 137.386 & 0.000 \\
\hline KM-DL- opportunities & 0.875 & 0.629 & 193.603 & 0.000 \\
\hline
\end{tabular}

The relationships among knowledge management, digital literacy and creating opportunities of 4.0 Industrial Revolution is shown that the relation between knowledge management and creating opportunity $(\mathrm{R})$ is 0.735 and the effect of relationship and the simultaneous contribution of variable ( $\mathrm{R}$ Square Change) is 0.540 or $54.0 \%$, which is good enough and other contribution $46.0 \%$ is from somewhere else or it is influenced by other variables not included or not discussed in this study. The significance of the test is shown that probability value of the test (Sig. F Change) or $\mathrm{p} 0.000<0.005$. And it is indicated that Ho is rejected and $\mathrm{Ha}$ is accepted. The conclusion, there is a relationship between knowledge management and opportunities for future job.

The relation between digital literacy and the opportunity in 4.0 Industrial Revolution is $(\mathrm{R})$ is 0.775 and the simultaneous contribution of variable ( $R$ Square Change) is 0.556 . It means that $55.6 \%$ which is good enough, this variable is contributed to the research and other $44.4 \%$ is influenced by other variables which is not in this research. The significance of the test is shown that probability value of the test (Sig. F Change) or p $0.000<0.005$. And it is shown that $\mathrm{Ho}$ is rejected and $\mathrm{Ha}$ is accepted. The conclusion, there is a relationship between digital literacy and opportunity of 4.0 Industrial Revolution.

The relation between knowledge management, digital literacy and opportunity of 4.0 Industrial Revolution is shown in $\mathrm{R}$ is 0.875 and the simultaneous contribution of these variables ( $\mathrm{R}$ Square Change) is 0.629 or $62.9 \%$ which is good. This variable is contributed to the research and other $37.1 \%$ is influenced by other variables which is not included in this research. The significance of the test is shown that probability value of the test (Sig. F Change) or $\mathrm{p} 0.000<0.005$. And it means that $\mathrm{Ho}$ is rejected and $\mathrm{Ha}$ is accepted. The conclusion, there is relationship among knowledge management, digital literacy and opportunity of 4.0 Industrial Revolution.

From data above, the research is shown the variables for each dimension is distributed normally. And the data is acceptable.

\section{Conclusion}

Gaps in digital learning arise in the Net Generation where they have a higher socioeconomic status, such as having a computer at home. Many of the staffs and employees find it difficult to learn digital literacy and are stored in documents as knowledge management [7]. This can hamper the progress of universities already starting with digital literacy. They must be motivated and encouraged so that behavior shows confidence in their abilities and 
skills in learning digital literacy. Self-efficacy can affect outcomes that reflect perceptions about abilities based on learned or experience. So, the university must persuade, encourage the members of university to learn [24]. For lecturers, teaching and researching are their job. They must train regularly every semester, and most of them moved to improve their digital literacy and their managing the knowledge. Some of the lecturers have slow learner and they mentioned to have training regularly (Interview with the lecturers). The students do not have problem with digital literacy, but their problem is to manage their knowledge and documented in the computer.

Knowledge management is very useful for everyone, especially workers, both managers and employees. By having knowledge management, all work can be documented, can be shared, and stored in a computer or other. Digital literacy must be studied through technology and the Internet so as not to be out of date which has entered the era of the industrial revolution 4.0. All work is done through Internet and technological changes must be addressed by learning continuously and by responding properly and correctly. Motivation and selfefficacy can convince all workers and students to face the era of the industrial revolution 4.0. With knowledge management and understand digital literacy, the university members are ready for sustainable learning in 21 st-century.

\section{References}

[1] V. Bhalla, S. Dyrchs and R. Strack, "Twelve forces that will radically change how organizations work.," Boston Consulting Grou[, Boston, 2017.

[2] R. Archean, Interviewee, The Use of Digital Literacy for Learning Process. [Interview]. 11 November 2019.

[3] B. Kirana, Interviewee, The Problem of Using Digital Literacy. [Interview]. 27 October 2019.

[4] S. Maisaroh, Interviewee, Difficulty of Using Digital Literacy in Learning Process. [Interview]. 27 October 2019.

[5] Foundation of Young Australia, "How are young people faring in transition from school to work?," Foundation of Young Australia, Melbourne, 2015.

[6] D. Crow, "Digital Literacy Unlock the Opportunity for All," COMCAST, 24 July 2014. [Online]. Available: https://corporate.comcast.com/values/csr/2018/opportunity-divide/digitalliteracy. [Accessed 29 January 2020].

[7] I. Hecker and P. . J. Loprest, "Now Hiring: Digital Literacy Skills Required," Urban Institute, 9 September 2019. [Online]. Available: https://www.urban.org/urban-wire/now-hiring-digitalliteracy-skills-required. [Accessed 29 January 2020].

[8] J. W. Cresswell, Research Design: Qualitative, Quantitative and Mixed Method Approaches, 4th Edition ed., V. Knight, Ed., Thousand Oak, California: SAGE Publication, Inc, 2014, p. 266.

[9] A. P. U. Siahaan and R. Rahim, "Dynamic Key Matrix of Hill Cipher Using Genetic Algorithm," International Journal of Security and its Applications, vol. 10, no. 8, pp. 173-180, 2016.

[10] R. Venkatesh and R. K. Sekhar, "User Activity Monitoring Using Keylogger," Asia Journal of Information Technology, vol. 15, no. 23, pp. 4758-4762, 2015.

[11] P. Tuli and P. Sahu, "System Monitoring and Security Using Keylogger," International Journal of Computer Science and Mobile Computing, vol. 2, no. 3, pp. 106-111, 2013.

[12] N. Adhikary, R. Shrivastava, A. Kumar, S. K. Verma, M. Bag and V. Singh, "Battering Keyloggers and Screen Recording Software by Fabricating Passwords," I. J. Computer Network and Information Security, vol. 2012, no. 5, pp. 13-21, 2012. 
[13] K. K. Soni, R. Vyas and A. Sinhal, "Importance of String Matching in Real World Problems," International Journal Of Engineering And Computer Science, vol. 3, no. 6, pp. 6371-6375, 2014.

[14] H. Nurdiyanto, R. Rahim and N. Wulan, "Symmetric Stream Cipher using Triple Transposition Key Method and Base64 Algorithm for Security Improvement," in International Conference on Information and Communication Technology 2017, Medan, 2017.

[15] K. Greene, "Transferable Digital Literacy Knowledge," The Language and Literacy Spectrum, vol. 28, no. 1, pp. 1-15, June 2018.

[16] K. Dalkir, Knowledge Management in Theory and Practice, Burlington, Massachussetts: Elsevier, 2005, pp. 217-244.

[17] L. Rainie and J. Anderson, "The Future of Jobs and Jobs Training," 3 May 2017. [Online]. Available: https://www.pewresearch.org/internet/2017/05/03/the-future-of-jobs-and-jobstraining/. [Accessed 10 February 2020].

[18] G. D. Bhatt, "Knowledge management in organisations: Examining the interaction between technologies, techniques, and people," Journal of Knowledge Management, vol. 5, no. 1, pp. 68-75, March 2002.

[19] A. Rahmah, "Digital Literacy Learning System for Indonesian Citizen," in The Third Information Systems International Conference, Indonesia, 2015. 